Metode Linguistik Historis Komparatif Bagi Epigrafi: Metode dan Analisis bagi Gejala Kebahasaan dalam Prasasti Berbahasa Jawa Kuna

\title{
Kayato Hardani
}

Keywords: inscription, letters, literature, language, comparison, ancient java

\section{How to Cite:}

Hardani, K. (2007). Metode Linguistik Historis Komparatif Bagi Epigrafi: Metode dan Analisis bagi Gejala Kebahasaan dalam Prasasti Berbahasa Jawa Kuna. Berkala Arkeologi, 27(2), 18-31. https:/ / doi.org/10.30883/iba.v27i2.950
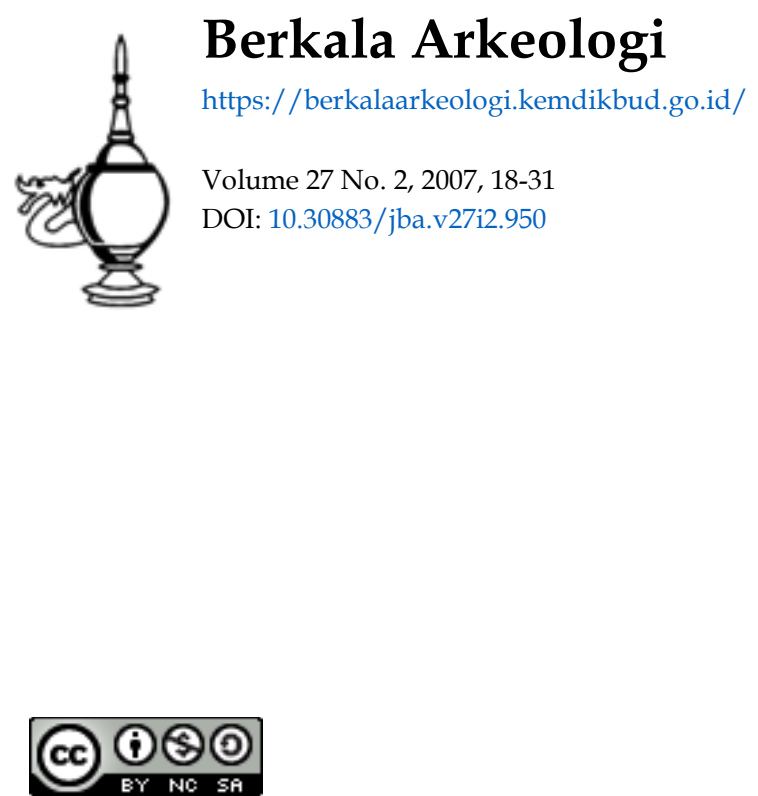

This work is licensed under a Creative Commons Attribution-NonCommercial-ShareAlike 4.0 International License. 


\title{
METODE LINGUISTIK HISTORIS KOMPARATIF BAGIEPIGRAFI : Metode dan Analisis bagi Gejala Kebahasaan dalam Prasasti Berbahasa Jawa Kuna
}

\author{
Kayato Hardani \\ (Balai Pelestarian Peninggalan Purbakala Yogyakarta)
}

\section{Epigrafi : Antara Arkeologi, Linguistik dan Sejarah}

Di dalam periode sejarah kuna Indonesia, prasasti adalah salah satu hasil budaya manusia masa klasik yang bersifat moveable disamping tinggalantinggalan yang bersifat unmoveable berupa bangunan-bangunan candi dan pertirtaan. Keberadaan prasasti secara makro tidak dapat dilepaskan dari wujud kebudayaan lain, seperti wujud nilai, wujud sistem perilaku dan wujud kebudayaan materi.

Prasasti merupakan wujud budaya materi ciptaan manusia yang di dalamnya mengandung ide gagasan manusia pada masanya, sehingga hubungan antara prasasti sebagai budaya materi dengan ide gagasan sebagai budaya nonmateri akan menghadirkan prasasti sebagai artefak yang mempunyai makna dan telah dihayati bersama oleh suatu kelompok sosial, komunitas masyarakat serta dianggap telah menyatu dengan lingkungan biofisik dan lingkungan sosialnya (Kartakusuma, 1998:1). Pada setiap kebudayaan selalu dijumpai tujuh unsur universal. Di dalam unsurunsur universal kebudayaan tersebut, bahasa adalah sebagai perekam kebudayaan sekaligus produk kebudayaan (Parera, 1991: 9).

Melalui bahasa pula pewarisan-pewarisan budaya dapat terjadi antar generasi. Di dalam suatu budaya, bahasa adalah sebuah sistem yang dapat hadir dalam dua bentuk yakni bahasa wicara dan tulisan. Keduanya merupakan medium yang berbeda, masing-masing memperlihatkan tata bahasa, kosakata, pembakuan dan kelaziman yang berbeda. 
"Speech and writing are two organs of the same human impulse- the conveyance of thought: the one operating through hearing, the other through sight; the one by sound from mouth to ear, the other by form or image from hand to eye" (Cameron, 1978: 40).

Dari hal tersebut tampak bahwa dalam studi arkeologi, prasasti menempati posisi sebagai artefak - sebagai benda ciptaan manusia yang berkebudayaan - sekaligus sebagai tinggalan tertulis yang memuat bahasa beserta maknanya yang telah membeku dalam wujud fisik prasasti. Tulisan merupakan sistem komunikasi antarmanusia dengan perantara tandatanda yang dilihat dan dipahami oleh pemakainya (Gelb, 1963: 12).

Kajian terhadap tulisan di atas bahan (lazim disebut sebagai epigrafi) diperlukan sebuah jalinan metode dari berbagai disiplin seperti arkeologi, sejarah dan linguistik sebagai upaya mengenali kembali gejala-gejala kebudayaan di masa lampau. Sampai saat ini kajian epigrafi secara mandiri dapat disebut 'bukan milik siapa-siapa' di antara ketiga ilmu tersebut, meski secara akademis kajian epigrafi dimasukkan dalam kurikulum studi arkeologi. Disiplin sejarah dengan obyek studi tinggalan tertulis termasuk di dalamnya prasasti menempatkannya pada derajat kesaksian tertinggi karena prasasti ditulis pada masa yang sejaman dengan penulisnya, meski tak dapat diabaikan pula adanya prasasti yang ditulis ulang (tinulad). 


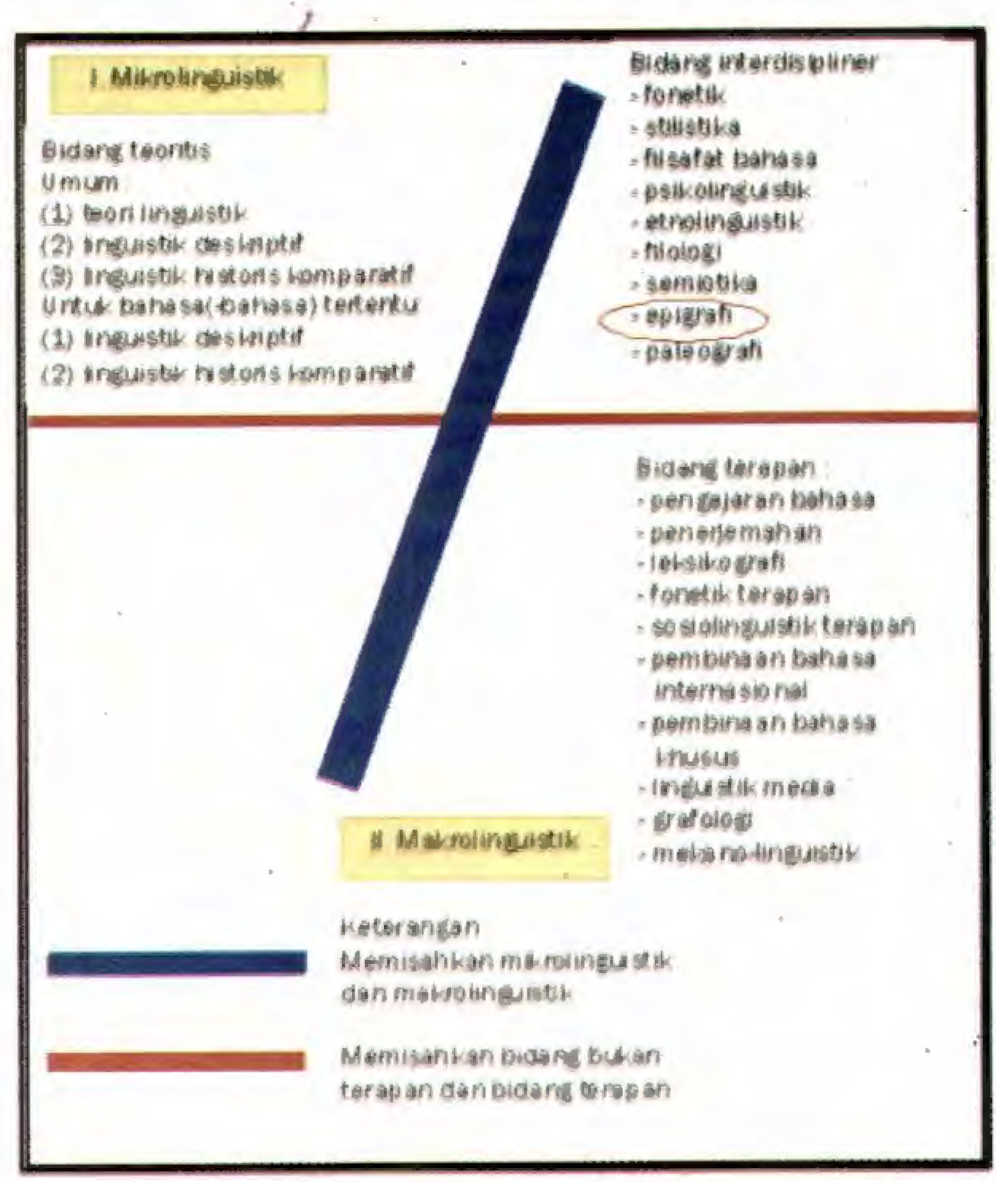

\section{Gambar 1 \\ Pembidangan Linguistik \\ (Dikutip dari Harimurti Kridalaksana, 1982: xxviii)}

Adapun dengan arkeologi yang secara epistemologis - metodologis mengkategorikan epigrafi hanya sebagai ilmu bantu (auxilliary science) dalam rangka merekonstruksi perikehidupan manusia masa lampau melalui tiga paradigmanya. Untuk studi linguistik juga sama halnya. Berikut adalah bagan sederhana yang dikutip dari Harimurti Kridalaksana (1982) dalam kaitannya dengan pembidangan linguistik yang secara jelas menampakkan posisi epigrafi dalam studi linguistik secara keseluruhan,

Secara khusus, arkeologi adalah ilmu yang berkenaar dengan kajian peninggalan budaya material manusia, namun pada kasus-kasus tertentu pun harus bersinggungan dengan berbagai tinggalan tertulis termasuk prasasti. Hal ini lebih dikaitkan dengan pemaknaan bahwa prasasti adalah 
budaya material ciptaan manusia yang secara kasat mata pada fisik artefak prasasti tersebut terdapat tinggalan ide gagasan yang ditorehkan di atas bahan (batu dan logam) dalam bentuk tulisan yang mewakili sebuah periode perkembangan bahasa tertentu. Maka tentu tidak salah bila muncul istilah text aided archaeology yang merupakan bagian dari kajian arkeologi kesejarahan (Ambary, 1998: 164). Lepas dari permasalahan mengenai "kepemilikan siapa" ilmu epigrafi, saat ini yang diperlukan adalah sebuah pendekatan holistik yang dapat sekaligus mengakomodasi kepentingan ilmu arkeologi, linguistik dan sejarah yang pada dasarnya adalah ilmu-ilmu tentang manusia yang berbudaya.

Posisi epigrafi di antara ilmu arkeologi, sejarah dan linguistik apabila digunakan hubungan rangkaian logika matematis dapat digambarkan secara sederhana dalam diagram Venn seperti berikut ini,

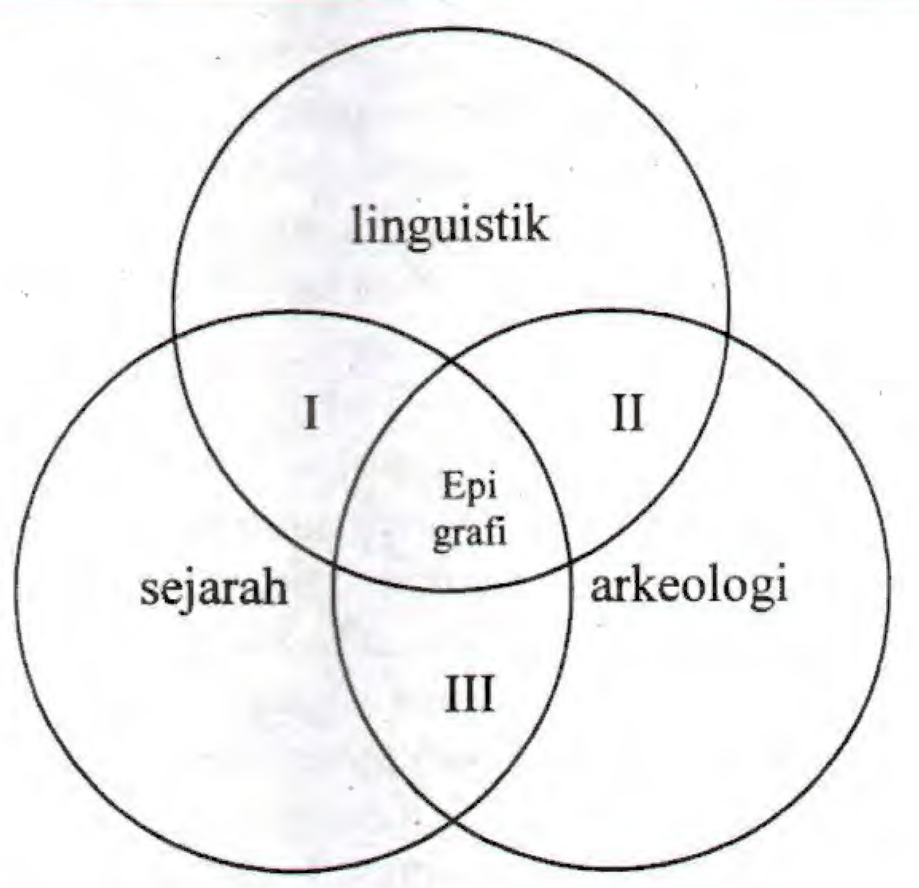

I Linguistik kesejarahan $\rightarrow$ linguistik diakronis II Arkeologi linguistik ?

III Arkeologi kesejarahan

Gambar 2

Diagram Venn yang menggambarkan

posisi epigrafi diantara ilmu Linguistik, Sejarah dan Arkeologi 
Tampak bahwa bidang singgung antara linguistik-arkeologi-sejarah terdapat sebuah 'ruang kecil' milik bersama. 'Ruang kecil' tersebut dapat diisi oleh epigrafi, karena di dalamnya terkandung sebuah unsur dari ketiga ilmu tersebut yakni bahasa. Maka setidaknya dengan kajian epigrafi - dengan menggunakan tiga pendekatan dari tiga ilmu tersebut - dapat diperoleh sebuah interpretasi bagi gejala kebudayaan manusia masa lampau lebih secara komprehensif. Pendekatan tersebut dapat dengan mengakomodasi teori maupun metode dari ilmu linguistik, sejarah dan arkeologi dengan melakukan sejumlah adaptasi yang terarah dan dapat dipertanggungjawabkan secara keilmuan. Apalagi saat ini khususnya teori dan metodologi dalam ilmu linguistik sebagai sebuah ilmu yang dinamis juga mengalami perkembangan yang cukup signifikan seiring kedinamisan gerak laju kebudayaan manusia modern. Kemajuan penelitian epigrafi sebagai sebuah kajian "mandiri" akan semakin nyata apabila ilmu arkeologi, linguistik dan sejarah tersebut senantiasa mengalami perkembangan teori dan metodologi yang pada akhirnya dapat berimbas bagi kemajuan penelitian epigrafi. Dengan epigrafi setidaknya metode, teori dan hipotesis dari ketiga ilmu tersebut dapat diadaptasi dan diuji kembali melalui data-data tertulis berupa prasasti sehingga gejala kebahasaan masa lampau dapat dideskripsikan atau dihipotesiskan secara lebih komprehensif.

\section{Kajian Bahasa dalam Arkeologi}

Suwedi Montana di dalam makalahnya pada PIA V 1989 dengan judul "Studi Tentang Arkeologi Linguistik Lingkup dan Terapannya" menyoroti dengan lugas trend penulisan-penulisan ilmiah pada PIA sejak tahun 1977 hingga 1986. Menampakkan bahwa penulisan ilmiah arkeologi khususnya penelitian arkeologi dalam kaitannya dengan fenomena kebahasaan belum banyak menampakkan pertambahan yang signifikan. Dengan menggunakan istilah "arkeologi linguistik", Montana menunjukkan bahwa sesungguhnya antara antara arkeologi dengan bahasa terdapat sebuah kaitan, yakni muncul sebagai bagian pada arkeologi kesejarahan " historical archaeology". Meski masing-masing ilmu yakni sejarah, linguistik dan arkeologi mempunyai silogisme-silogisme berbeda-beda di dalam pemecahan masalah kebudayaan (Montana, 1987: 193). 
Keterkaitan antara arkeologi linguistik dengan arkeologi kesejarahan juga terungkap dalam gagasan Colin Renfrew dalam bukunya Archaeology and Language (1987) yang secara lebih spesifik menjelaskan bidang garap arkeologi linguistik. Di dalam buku tersebut, Renfrew lebih banyak mengambil contoh kasus keterkaitan antara tinggalan arkeologis (material culture) dan bahasa dalam kaitannya dengan persebaran dan sejarah bahasa dan bangsa Indo Eropa. Interpretasi yang diperoleh dari penelitian Renfrew menunjukkan bahwa terdapat proses perubahan budaya yang beriringan dengan perubahan jejak-jejak rekaman arkeologis (Renfrew, 1987: 286)

Kajian ilmu linguistik sendiri secara teoritis dimensi waktu (temporal) penelitiannya dibedakan menjadi dua yakni linguistik diakronik dan linguistik sinkronis. Linguistik diakronik merupakan analisis bahasa yang dilakukan dalam waktu yang tidak sezaman dengan peneliti atau dengan kata lain mempelajari bahasa dalam fase-fase perkembangan dari zaman ke zaman. Linguistik diakronik dibedakan dengan istilah linguistik sinkronik yang mempelajari bahasa dari gejala-gejala yang bersifat sezaman (Jos Daniel Parera, 1991: 21)

Linguistik diakronik sering pula disebut sebagai linguistik historis komparatif. Penyebutan semacam itu erat kaitannya dengan metode yang digunakan yakni melalui komparasi pada bahasa-bahasa sekerabat. Metode ini lebih menggantungkan pada korespondensi bunyi dan makna pada kata-kata kognat. Korespondensi bunyi merupakan perubahan bunyi yang muncul secara teratur dalam bahasa-bahasa sekerabat yang sering dinyatakan dalam hukum atau kaidah perubahan bunyi. Contohnya adalah Hukum Grimm yang berlaku bagi bahasa rumpun Indo Eropa, serta Hukum van der Tuuk untuk bahasa rumpun Austronesia.

Secara sederhana metode linguistik komparatif ini dapat dipahami dengan melakukan perbandingan antara bahasa pada tataran lebih rendah dengan bahasa pada tataran lebih tinggi yang sifat kajiannya diakronis (tak sezaman). Bahasa pada tataran lebih rendah ini adalah bahasa-bahasa lokal yang terdapat secara regional misalnya bahasa Sunda dan bahasa Madura. Sedangkan bahasa pada tataran lebih tinggi adalah bahasa hasil 
rekonstruksi, misalnya bahasa Proto Malayo Javanic dan bahasa Proto Austronesia.

Perlu untuk digarisbawahi mengenai metode komparatif ini adalah jamak dipakai untuk kata-kata dari bahasa yang masih sekerabat, metode ini dimulai dari pengumpulan kata-kata dengan bentuk dan makna yang mirip melalui teknik leksikostatistik. Sehingga pada salah satu mekanisme penelitiannya sejumlah kata yang bukan berkerabat atau merupakan kata pinjaman akan dianalisis secara terpisah, atau kadang tidak dilakukan analisis sama sekali.

Kata tidak sekerabat yang muncul sebagai kata pinjaman dalam sebuah rekonstruksi bahasa mempunyai hubungan yang timbal balik. Artinya semakin tepat rekonstruksi bahasa maka semakin mudah penentuan kata pinjaman, atau semakin banyak kata pinjaman yang ditentukan maka semakin mudah pula dalam melakukan rekonstruksi bahasa (Collins, 1981: 11). Untuk kosakata pinjaman, metode komparatif dilakukan dengan membandingkan antara kata pinjaman dengan kata dari bentuk aslinya. Hasilnya akan diperoleh perubahan bunyi yang sifatnya sekunder (variasi) dan juga sejumlah perubahan morfologi maupun semantik

Perunutan kembali bentuk asal dari sebuah kosakata pinjaman maupun kata-kata kognat dalam sebuah bahasa disebut juga sebagai kajian etimologi (sejarah kata), karena etimologi juga bersifat diakronis yakni dengan melakukan komparasi-komparasi unsur bahasa seperti pada tataran fonologi, morfologi maupun tingkat makna (semantik). Dari kajian semacam itu diharapkan diperoleh pemahaman tentang sejumlah perubahan-perubahan bahasa yang pernah terjadi. Pada umumnya perubahan pada tataran bahasa seperti fonologi, morfologi dan semantik dapat dijelaskan sebab-sebabnya secara linguistis, yakni melalui bidangbidang interdisipliner yang ada dalam ilmu linguistik misalnya sosiolonguistik, etnolinguistik, dan semiotik. Berikut adalah diagram alir secara sederhana logika berpikir dalam metode linguistik komparatif, 


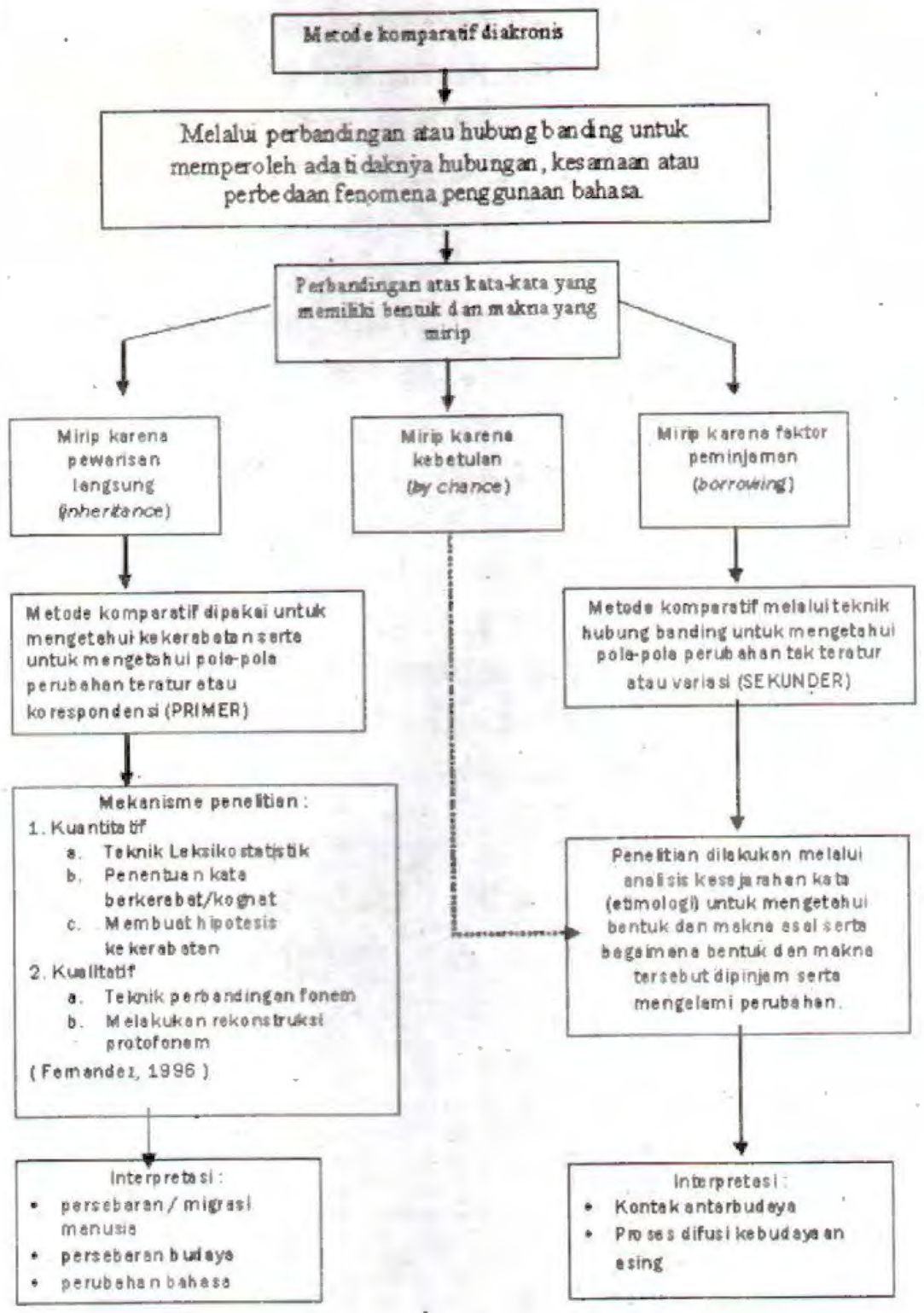

\section{Ranah Bagi Kajian Epigrafi : Prasasti Sebagai Data}

Metode linguistik historis komparatif pada dasarnya dapat diterapkan dan dipakai sebagai perangkat analisis atas gejala kebahasaan yang dijumpai di dalam prasasti. Adaptasi atas sejumlah perangkat metodologi linguistik historis komparatif bagi epigrafi dapat dilaksanakan melalui dua jalur yang berbeda mekanisme analisisnya. 
Pertama, melalui jalur kesamaan bentuk dan makna karena pewarisan langsung (inheritance). Penelitian semacam ini di dalam pelaksanaannya metode komparatif tidak dapat dilaksankan sepenuhnya. Beberapa kendala adalah tidak diketahuinya bunyi (fonologi) atas sebuah kata atau sebuah fonem. Untuk data epigrafi kita hanya memperoleh tulisan dengan tiada pengetahuan sedikitpun mengenai sistem bunyinya. Meskipun demikian kadang dijumpai korelasi-korelasi bunyi antara bahasa kuna - dalam hal ini adalah bahasa Jawa Kuna - dengan bahasa Jawa Modern. Selain itu setidaknya melalui abjad Jawa Kuna dapat ditelusuri kembali bunyibunyinya, karena abjad tersebut dibuat sebagai simbol bunyi yang dibedakan dari daerah artilkulasi bunyi yang dimiliki manusia (labial, palatal, dental). Dalam analisis semacam ini bahasa Jawa Kuna -yang dipakai dalam prasasti- dikomparasikan dengan bentuk bahasa rekonstruksi pada tataran lebih lebih tinggi (Proto Malayo Javanic atau Proto Autronesia) atau juga dapat dikomparasikan dengan bentuk bahasa Jawa Modern yang masih dipakai sampai saat ini. Dapat dicontohkan dalam tabel berikut:

\begin{tabular}{|c|c|c|c|}
\hline $\begin{array}{c}\text { Bahasa } \\
\text { Proto } \\
\text { Austronesia }\end{array}$ & $\begin{array}{c}\text { Bahasa Jawa } \\
\text { Kuna }\end{array}$ & $\begin{array}{c}\text { Bahasa Jawa } \\
\text { Modern }\end{array}$ & Arti \\
\hline${ }^{*}$ juruq & juru & juru & $\begin{array}{c}\text { Juru, } \\
\text { tukang }\end{array}$ \\
\hline${ }^{*}$ tajiq & taji & taji & Taji \\
\hline${ }^{*}$ habuq & hawu & awu & Abu \\
\hline \multicolumn{3}{|c}{ (Kumoro, 2001: 21,25) }
\end{tabular}

Hasil dari komparasi bahasa yang sifatnya diakronis tersebut dapat diperoleh bentuk-bentuk perubahan bahasa yang sifatnya internal, misalnya perubahan bunyi (fonologi) dan kosakata sejak dahulu hingga sekarang.

Selain metode komparatif seperti hal tersebut di atas, juga dapat dilakukan dengan teknik pengumpulan kosakata dasar atau leksikostatistik. Teknik leksikostatistik yang dilakukan terhadap kosakata bahasa Jawa Kuna yang dijumpai dalam prasasti yakni dengan mengumpulkan sejumlah kata benda dan kata kerja. Teknik semacam ini didasarkan pada asumsi bahwa bahasa 
tidak akan mengalami perubahan yang berarti selama dari seribu tahun, seperti yang dikemukakan oleh Morris Swadesh (1962). Kajian leksikostatistik yang pernah dilakukan dengan objek prasasti adalah penelitian Djoko Dwiyanto (1986). Hasil penelitian tersebut menujukkan bahwa perubahan dalam penulisan, pemakaian dan penyebutan suatu kata tidak mempengaruhi arti dan pengertiannya (Dwiyanto, 1986: 61). Berikut adalah sejumlah contoh yang dikutip dari penelitiannya tersebut.

\begin{tabular}{|c|c|c|}
\hline $\begin{array}{c}\text { Bahasa Jawa } \\
\text { Kuna }\end{array}$ & $\begin{array}{c}\text { Bahasa Jawa } \\
\text { Modern }\end{array}$ & Arti \\
\hline Alap & alap & Mengambil \\
\hline duhilat & dilat & Jilat \\
\hline Dwal & adol & Jual \\
\hline \multicolumn{2}{|c}{ (Dwiyanto, 1986:22) }
\end{tabular}

Jalur kedua yakni melalui komparasi atas kesamaan bentuk dan makna karena peminjaman (borrowing). Analisis yang dilakukan adalah melalui kajian etimologi yakni menelusuri kembali sejarah asal kata serta untuk mengetahui bentuk-bentuk perubahan yang terjadi pada bahasa peminjam pada tataran fonologi, morfologi dan semantik. Kajian etimologi dilakukan dengan melakukan teknik hubung banding atas sejumlah kata pinjaman yang dijumpai di dalam prasasti. Bahasa asing yang banyak dipinjam dalam bahasa Jawa Kuna adalah bahasa Sanskerta. Kemunculan unsur serapan bahasa Sanskerta di dalam prasasti merupakan ciri idiolek seorang citralekha sebagai individu yang menulis teks prasasti. Ciri idiolek tersebut merupakan ciri khas setiap orang yang lebih sering dipengaruhi oleh lingkungan sosial budaya, lingkungan alam dan tingkat pendidikannya (Hardani, 2004 : 165 ).

Sejumlah unsur serapan tersebut setelah dilakukan kajian etimologi akan menampakkan sebagai unsur retensi atau inovasi eksternal. Muncul sebagai unsur retensi apabila kata yang dipinjam tidak mengalami perubahan baik dalam fonologi, morfologi dan makna katanya, demikian kebalikannya jika unsur serapan tersebut telah mengalami perubahan maka telah terjadi inovasi yang dapat terjadi pada tataran-taran bahasa tersebut. Dapat dicontohkan misalnya pada kata hala yang berasal dari bahasa 
Sanskerta yan berarti "bajak". Kata ini bisa muncul sebagai retensi yakni sebagai "bajak" seperti dalam konteks kalimatnya sebagai "barang dagangan" ...tambaga gansa wsi hala yali kadut ... (prasasti Ayam Teas III $901 \mathrm{M})$, tetapi dapat pula muncul sebagai bentuk hibrid dengan penambahan prefiks khas bahasa Jawa kuna mahala (prasasti Taji 901 M) yang berarti "petani". Meskipun demikian konteks kalimat harus tetap diperhatikan di dalam penentuan sebuah arti kata serapan dalam prasasti. Dari hal tersebut tampak jika kata Sanskerta telah dihibridkan dengan unsur khas bahasa Jawa Kuna yang pada akhirnya diperlakukan secara luwes yang disesuaikan dengan keinginan makna yang akan diharapkan oleh pemakai bahasa. Akibatnya unsur pinjaman tersebut seolah telah menjadi bagian dai sistem bahasa peminjam (bahasa Jawa Kuno).

Namun dalam beberapa kasus, sejumlah kata serapan tidak bisa dijelaskan secara gamblang asal-usulnya. Apakah kata tersebut muncul sebagai kesamaan karena pinjaman atau kesamaan karena kebetulan. Dapat dicontohkan pada kata kapas (prasasti Sangsang 907 M) dan kapur. Kedua kata tersebut apabila dilakukan kajian etimologi berasal dari kata bahasa Sanskerta karpasa dan karpura yang artinya "tanaman kapas (Gossypium indicum)" dan "kapur". Tetapi bila dilakukan perbandingan dengan bahasa rekonstruksi lebih yang tinggi, kata tersebut diperkirakan merupakan kosakata asli dari bahasa Proto Austronesia yakni *kapas dan *kapur. Akibatnya dapat memunculkan dua kemungkinan mengenai hal tersebut yakni kata tersebut telah dipinjam oleh para penutur bahasa Proto Austronesia yang belum terpisah-pisah dan kemudian kata pinjaman tersebut diwariskan secara internal. Kemungkinan kedua adalah karena kesamaan bentuk kata tersebut karena kebetulan sebagai akibat adanya universalismie ciri bahasa dalam bahasa, morfem, kalimat dan konstruksi (Hardani, 2004: 112).

Pada dasarnya kajian etimologi atas sejumlah kata serapan bahasa asing yang muncul di dalam bahasa Jawa Kuna dapat memberi pemahaman yang paling mendasar atas suatu kata pinjaman. Kemunculan kosakata pinjaman dalam sebuah bahasa pribumi dapat diidentifikasikan sebagai :

1. Gejala sosiolinguistik, yakni erat kaitannya dengan kontak dan interaksi antarbudaya. Wujud gejala sosiolinguitis seperti muncul sebagai peristiwa interferensi, diglosia, bilingulisme dan bilingualitas. 
2. Gejala snobisme bahasa yakni dicirikan dengan banyaknya kosakata pinjaman yang terdapat dalam gaya berbahasa maupun tulisan. Gejala ini lebih banyak dipengaruhi oleh tidak tersedianya padanan makna dari setiap kata yang akan dipakai.

3. Gejala arkaisme. Gejala semacam ini lebih sering muncul dalam karya sastra untuk memberikan sebuah rasa klasik pada karya sastra yang dihasilkan.

Selain melalui jalur etimologi seperti tersebut di atas, komparasi atas kosa kata asing juga bisa dilakukan secara internal yakni dengan metode errors analysis. Metode ini merupakan sebuah metode untuk mengetahui dan memperbaiki kesalahan pemakaian tata bahasa dalam kalimat. Khususnya kesalahan pemakaian kosakata asing dalam sebuah prasasti berbahasa non-Jawa Kuna, misalnya terhadap prasasti berbahasa Sanskerta. Penelitian semacam ini pernah dilakukan terhadap tiga prasasti berbahasa Sanskerta dari Situs Kraton Boko yakni prasasti Krtikavasalinga, Haralinga dan Tryamvakalinga. Diketahui bahwa kesalahan penggunaan bahasa Sanskerta di dalam ketiga prasasti tersebut cenderung acak, tidak konsisten meski ditemukan kalimat yang menggunakan tata bahasa yang benar, dan juga munculnya pengaruh bahasa Jawa kuna di dalam penggunaan bahasa Sanskerta (Yusiani, 2007: 208)

Kehadiran kata pinjaman yang muncul di dalam suatu bahasa pribumi lebih sering diakibatkan karena adanya kontak budaya. Kontak budaya antara dua kebudayaan yang berbeda akan menimbulkan perubahan budaya, baik terjadi secara ekstrem atau dengan pengadaptasian. Oleh karena itu studi. yang mendalam atas segi kebahasaan pada tinggalan tertulis terutama prasasti dari periode yang paling awal hingga periode-periode akhir perlu untuk dilakukan.

\section{Epilog}

Kajian bahasa di dalam prasasti masih membuka peluang yang besar bagi rekonstruksi perikehidupan manusia masa lampau. Perangkat-perangkat teoritis beserta silogisme-silogisme dalam ilmu linguistik khususnya perlu untuk dimanfaatkan secara maksimal bagi kemajuan kajian epigrafi. Sehingga sumbangan penelitian kebahasaan dalam prasasti akan mengisi 
sebuah faset rekonsruksi sejarah kuna Indonesia yang masih banyak yang kosong.

\section{KEPUSTAKAAN}

Collins, James Thomas, 1981. "Ilmu Linguistik Sejarah : Asas, Faedah dan Hasilnya", dalam Dewan Bahasa, Oktober, Kuala Lumpur.

Dwiyanto, Djoko, 1986 "Manfaat Studi Bahasa Dalam Prasasti Terhadap Perkembangan Studi Kebudayaan Jawa Kuno (Suatu Studi Rintisan)", Laporan Penelitian. Yogyakarta : Universitas Gadjah Mada.

Fernandez, Inyo Yos, 1996. Relasi Historis Kekerabatan Bahasa Flores, Kajian Linguistik Historis Komparatif Terhadap Sembilan Bahasa di Flores, Flores: Penerbit Nusa Indah.

Gelb, I.J, A 1963. Study of Writing, Chicago: The University of Chicago Press.

Hardani, Kayato. 2004 "Penggunaan Unsur Serapan Bahasa Sanskerta Dalam Prassati-Prasasti Masa Pemerintahan Rakai Watukura Dyah Balitung (898 - 910 M ) : Suatu Kajian Etimologi", Skripsi.Yogyakarta: Fakultas IImu Budaya Universitas Gadjah Mada

Hendrokumoro, 2001. "Beberapa Perubahan Bentuk Bahasa Jawa (Dahulu dan Saat Ini)", Laporan Penelitian. Yogyakarta: Universitas Gadjah Mada

Kartakusuma, Richadiana, 1998. "Persebaran Prasasti Berbahasa Melayu Kuna di Pulau Jawa", makalah dalam EHPA 16-20 Februari 1998, Cipayung

Kridalaksana, Harimurti, 1982. Kamus Linguistik, Jakarta: PT Gramedia.

Montana, Suwedi, 1989. "Studi Tentang Arkeologi Linguistik, Lingkup dan Terapannya", makalah dalam PIA V 
Parera, Jos Daniel, 1991. Kajian Linguistik Umum, Historis Komparatif dan Tipologi Struktural, Jakarta: Penerbit Erlangga.

Renfrew, Collin, 1987. Archaeology and Language, London: Penguin Books

Yusiani, Anne Putri,2007. "Tiga Prasasti Dari Bukit Baka 778 Saka : Suatu Telaah Penggunaan Tata Bahasa Sanskerta", Skripsi. Jakarta: Fakultas IImu Pengetahuan Budaya, Universitas Indonesia. 